Copyright (C) 2019 by Academic Publishing House Researcher

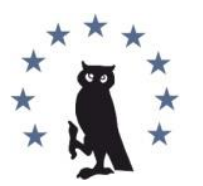

Published in the Russian Federation

European Researcher. Series A

Has been issued since 2010.

E-ISSN 2224-0136

2019, 10(1): 59-65

DOI: 10.13187/er.2019.1.59

www.erjournal.ru

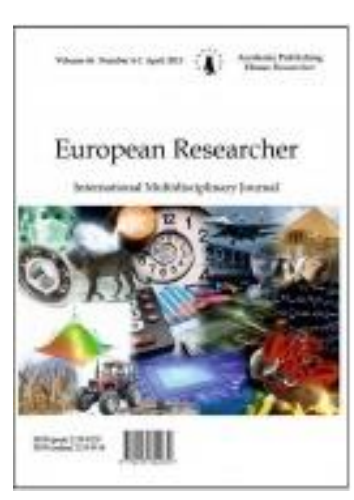

\title{
Possibilities of Development of Balance Abilities in Ski Jumping by Gymnastics
}

\author{
Michaela Slováková a, Elena Bendíková a ${ }^{\text {, * }}$, Annetta Müller b \\ a Matej Bel University, Faculty of Arts, Banská Bystrica, Slovakia \\ ${ }^{\mathrm{b}}$ University of Debrecen, Debrecen, Hungary
}

\begin{abstract}
In the present paper, the author is publishing the partial results of possibilities of development of balance movement abilities in ski jumping. The main aim of the study was to do research in the changes to the level of balance abilities of the respondents after having attended 12-week long preparation. The main research method consisted of a two-group pedagogical experiment with the experimental agent represented by the proposed movement programme including the elementary and conditioning gymnastics. The current level of the movement abilities in question was diagnosed by an entry and exit examination with standardized motorics tests. Based upon the processed and statistically verified results we can confirm that the experimental agent has caused positive changes to balance abilities and therefore the movement programme we created may be regarded as effective.
\end{abstract}

Keywords: balance abilities, movement programme, gymnastics, the youngsters.

\section{Introduction}

Coordination abilities as one of the main components of movement precondition of an individual play a key role in sportsmen's performance in various types of sports. By Měkota (2005) they can be referred to as generally functioning performance prerequisite, which are not, however, considered as the only one factor of sports performance. Our paper deals with development of movement abilities while Měkota (2005) defines them as an ability to maintain the line of gravity of our body or to reestablish such balance even in changeable conditions of the external environment. It is a so-called limitating precondition for ski jumpers, which is not only the level of the static balance ability to maintain the body in an unsteady position, but also the dynamic ability during the flying period when it is important to maintain or reestablish the balance during a nonsupport movement phase.

Lednický \& Doležalová (2002) define balance abilities as the ability to maintain the line of gravity of a body in course of as well as after extensive repositioning of a body, which depends upon the surface of support, the position of the centre of gravity of a body, the influence of analyzers and external factors.

They claim a lot can be changed through a systematic and planned training and emphasize merging of movement activities into one sequence. As stated by Strešková (2005), balance abilities can be improved by isometric strenghtening of postural muscles, trainability of a vestibular analyzer and complete exercise for development of balance - balancing.

\footnotetext{
${ }^{*}$ Corresponding author

E-mail addresses: elena.bendikova@umb.sk (E. Bendíková)
} 
Neuman (2003) assumes that both static and dynamic balance play an essential role when maintaining the upright body position in relation to gravity and force affecting the standing position in static balance or the movement in dynamic balance. In addition hereto, Strešková (2010) also deals with the issue of statistic significance and interdependence of statistic balance of a vestibular analyzer. She is trying to clarify how the value of static balance and the level of a vestibular analyzer change in case of preschool children and younger pupils after two-year long gymnasticst preparative classes.

The research describes the improvement in the two areas. The similar research was documented by Tonkovicová (2010) who confirms that gymnastics preparation had a positive impact on trainability of a vestibular analyzer yet in comparison with another control group not having focused on gymnastics preparation, was not statistically important whatsoever. On the basis of the applied research, Rupčík (2010), however, claims that gymnastics preparation consisting of the elements of elementary and conditioning gymnastics had a significant impact on the acquired level of static balance and the level of a vestibular analyzer. Böhmerová (2006) deals with the development of balance abilities from the physiological point of view. Simultaneously Böhmerová (2007) points out that the level of static balance of gymnasts aged 8 to 10 depends upon their gymnastics performance as well as their age. It is obvious that the differences in performance were much more distinctive once the intensity increased. On the other hand, the author confirms that the standard attitude does not necessarily depend on the level of gymnastics performance. The paper by Plešivčáková (2013) demonstrates that a provable impact of gymnastics practice on the entire development of a sportsman's body contributes to the overall development of coordinative and conditioning abilities, mainly the strength, speed, movability or specific performance as well as perfectness of muscles, spatial orientation and balance abilities. It applies the elements of gymnastics practice along with rotations around a body axis and body positions with the head down, thus, among other things, improving the functions of a vestibular aparatus. Proprioceptive system brings the qualification required for the person's accordance with environment and providing adaptation. It is the sense that assures understanding the position of the joints when one closes his eyes. By virtue of this information, people busy with sports need to improve the proprioception sense in order to reduce their mistakes, prevent injuries and increase their success (Liberum Montessori Akademia, 2017). Other authors have focused on the development and diagnostics of balance abilities, e.g. Potop, Grigore da Gavojdea (2015), for gymnastics girls, or Havel, Hnízdil et al. (2010), following development of movement abilities in various sports areas as well as Laczo et al. (2013), Perečínska (2006), Belej, Junger et al. (2006), Moravec, Kampmiller, Sedláček (2002), Kasa (2002), Paugschová, Daubnerová, Ondrášek (2010), Mandzák, Slováková, Krull (2018), Mandzák, Mandzáková (2002), etc. Finally it is important to emphasize that general principles have to be respected when improving balance abilities. As stated by Perič (2004) it mainly relates to: respecting sensitive periods of development, using more complex coordination practice, a gradual increase in complexity of practice, variability of exercises and use of a large set of training instruments, applying practices in the initial period of training right after the warm-up, preferring more practice with a lower number of repetitions and series, a relatively low volume, a higher frequency of impulses within a micro-cycle period, a sufficient relaxation interval and transfer from stable to variable conditions.

Aim. The main aim of the paper was to verify the effectivity of the movement gymnastics programme we have created for the level of development of balance abilities in ski jumping. In our research we assumed that the experimental agent would have an impact on the statistically considerable improvement of balance abilities within an experimental group.

\section{Materials and methods}

The research group consisted of ski jumpers $(n=12)$ with the average age of 7.16 from the sports clubs KPSL and SKL Banská Bystrica. The sample was divided into an experimental and a control group. The experimental group was made of 6 probands, the members of the ŠKL Club Banská Bystrica with the average height of $128.16 \mathrm{~cm}$ (cca $4.2 \mathrm{ft}$ ) and average weight of $23.35 \mathrm{~kg}$ (cca $51.4 \mathrm{lb}$ ). The control group consisted of the same number of probands, i.e. 6 members of the KPSL Club Banská Bystrica with the average height of $127.16 \mathrm{~cm}$ (cca $4.1 \mathrm{ft}$ ) and average weight of $22.85 \mathrm{~kg}$ (cca $50.3 \mathrm{lb}$ ). In order to achieve the given goal we carried out a twelve-week long and two-group pedagogical experiment from March 2017 to May 2017. The experimental agent applied into the 
training practice of the experimental group included a movement programme with the elements of basic and conditioning gymnastics with the control group taking up the training practice in unchanged conditions. In order to find out about the current level of balance abilities of the overall research group, we carried out the initial entry and final exist testing. Please find only the partial results of the following tests: Test 1 - The flamingo on the right and left lower limb and Test 2 Modified flamingo on the right and left lower limb.

Test 1 - Flamingo The test of stability in the standing position on either a right or a left lower limb. An individual stands unbooted on the full sole of the foot with a free lower limb bended in the knee and hip joints and the sole of the foot attached to the inward side of the knee of the standing foot, arms akimbo and telling a timekeeper to start the stopwatch. The point is to maintain the body in a balanced position as long as possible, max. 6o seconds. The test is completed once the position has been interrupted, the individual has moved from the place or touched the ground with any part of the body, has moved the arms away from the hips, etc. The test is repeated two times with better results to be documented in seconds (Moravec et al., 2002).

Test 2 - Modified flamingo The test of ability in the standing position either on a right or a left lower limb without visual control. An individual stands unbooted on the full sole of the foot with a free lower limb bended in the knee and hip joints and the sole of the foot attached to the inward side of the knee of the standing foot, arms akimbo, closes the eyes and telling a timekeeper to start the stopwatch. The point is to maintain the body in a balanced position as long as possible, max. 60 seconds. The test is completed once the position has been interrupted, the individual has moved from the place or touched the ground with any part of the body, has moved the arms away from the hips, etc. The test is repeated two times with better results to be documented in seconds (Perečinská, 2006).

In order to determine statistical significance of the differences in measurements within the experimental and the control group, we applied Wilcoxon test while the MannWitney U-test was used to compare and contrast the changes to the level of balance abilities between the experimental and the control group by way of the identical parameters.

\section{Results and discussion}

The values we obtained in course of the entry and exit testing were evaluated and compared in order to determine their statistical significance. The level of static balance abilities was tested by a so-called flamingo exercise. Firstly we diagnosed balance abilities by the flamingo test on the right lower limb. After a twelve-week long practice the two groups reported an increase in the studied balance ability. Table 1 shows the statistical evaluation of the data.

Table 1. Statistical evaluation of the differences in the flamingo test on the right lower limb

\begin{tabular}{|c|c|c|c|c|c|}
\hline \multicolumn{6}{|c|}{ Flamingo on the right lower limb } \\
\hline & $\begin{array}{l}\text { Statistical } \\
\text { charateristics }\end{array}$ & $\begin{array}{l}\text { Input } \\
\text { (s) }\end{array}$ & $\begin{array}{l}\text { Wilcoxon } \\
\text { test }\end{array}$ & $\begin{array}{l}\text { Output } \\
\text { (s) }\end{array}$ & $\begin{array}{l}\text { Mann W } \\
\text { U-test }\end{array}$ \\
\hline \multirow{3}{*}{$\begin{array}{l}\text { Experimental } \\
\text { group }\end{array}$} & $\mathrm{Me}$ & 42 & \multirow{3}{*}{$\mathrm{p} \leq 0.05$} & 50.72 & \multirow{6}{*}{$\mathrm{p} \leq 0.05$} \\
\hline & $\mathrm{X}$ & 44.86 & & 51.42 & \\
\hline & $\mathrm{Vr}$ & 25.55 & & 20.14 & \\
\hline \multirow{3}{*}{$\begin{array}{l}\text { Control } \\
\text { group }\end{array}$} & $\mathrm{Me}$ & 40.67 & \multirow{3}{*}{$\mathrm{p} \leq 0.05$} & 42.51 & \\
\hline & $\mathrm{X}$ & 43.98 & & 45.9 & \\
\hline & $\mathrm{Vr}$ & 32.2 & & 26.4 & \\
\hline
\end{tabular}

Legend: Me- median, $\mathrm{X}$ - average value, $\mathrm{Vr}$ - variability range, Wilcox. Test-Wilcoxon test, Mann W. U-test - MannWitney U - test, s - seconds, p - statistical significance

The key role of the probands in the flamingo testing was to form a balance upright position on one foot for the longest time possible, min. 6os. In the entry testing, the experimental group reported the average value of 44.86s. The implementation of the movement programme into the training practice resulted in a change as the exist testing reported the average value of 51.42s, 
which accounts fo average improvement of 6.56s. In the entry testing, the control group reported the average value of balance position of $43.89 \mathrm{~s}$ with $45.9 \mathrm{~s}$ in the exit testing, which represents an increase by 2.01s. In order to define changes to the level of static balance we did a flamingo testing on the lower right limb and based upon the Wilcoxon test we reported five-percent statistical significance $(\mathrm{p} \leq 0.05)$ in the overall research group. The comparison of the differences of the studied movement abilities by the Mann Witney U-test confirmed statistical significance of $\mathrm{p} \leq \mathrm{0,05}$ for the benefit of the experimental group. Entry and exit measurements of the flamingo test on the left lower limb confirmed positive changes to the level of balance abilities (see the Table 2).

Table 2. Statistical evaluation of the differences in the flamingo test on the left lower limb

\begin{tabular}{|c|c|c|c|c|c|}
\hline \multicolumn{6}{|c|}{ Flamingo on the left lower limb } \\
\hline & $\begin{array}{l}\text { Statistical } \\
\text { characteristic }\end{array}$ & $\begin{array}{l}\text { Input } \\
\text { (s) }\end{array}$ & $\begin{array}{l}\text { Wilcoxon } \\
\text { test }\end{array}$ & $\begin{array}{l}\text { Output } \\
\text { (s) }\end{array}$ & $\begin{array}{l}\text { Mann W } \\
\text { U-test }\end{array}$ \\
\hline \multirow{3}{*}{$\begin{array}{l}\text { Experimental } \\
\text { group }\end{array}$} & $\mathrm{Me}$ & 43.64 & \multirow{3}{*}{$\mathrm{p} \leq 0.05$} & 49.5 & \multirow{6}{*}{$\mathrm{p} \leq 0.05$} \\
\hline & $\mathrm{X}$ & 44.54 & & 50.66 & \\
\hline & $\mathrm{Vr}$ & 29.52 & & 21.55 & \\
\hline \multirow{3}{*}{$\begin{array}{l}\text { Control } \\
\text { group }\end{array}$} & $\mathrm{Me}$ & 41.94 & \multirow{3}{*}{$\mathrm{p} \leq 0.05$} & 45.71 & \\
\hline & $\mathrm{X}$ & 42.18 & & 43.80 & \\
\hline & $\mathrm{Vr}$ & 33.89 & & 36.14 & \\
\hline
\end{tabular}

Legend: $\mathrm{Me}$ - median, $\mathrm{X}$ - average value, $\mathrm{Vr}$ - variability range, Wilcox. Test-Wilcoxon test, Mann W. U-test - MannWitney U - test, s - seconds, $p$-statistical significance

Before the experiment, the experimental group reported an average value of $44.54 \mathrm{~s}$ with the average of 50.66s in the exit testing after applying the movement programme, which is an average increase of 6.12s after the experiment. In the initial testing, the probands of the control group reported average performance of $42.18 \mathrm{~s}$ in the balance position with the average increase of $1.62 \mathrm{~S}$ in the exit testing, which is much lower in comparison with the experimental group - 43.80s. In the flamingo test on the left lower limb we diagnosed the changes to the level of balance abilities with five-percent statistical significance between the entry and exit values by way of the Wilcoxon test in both the experimental and the control group $(\mathrm{p} \leq \mathrm{0}, 05)$. In case of the experimental agent, i.e. the movement programme with gymnastics elements, the Mann Witney U-test reported a significant difference on the level of statistical significance of $\mathrm{p} \leq 0,05$ for the benefit of the experimental group, which proves the effectivity of the implemented programme.

For objective evaluation of the current level of balance abilities in ski jumping, we carried out the test "modified flamingo" on the right and left lower limbs. Table 3 shows the changes to balance abilities diagnosed on the right lower limb.

Table 3. Statistical evaluation of differences in the test of modified flamingo on the right lower limb

\begin{tabular}{|c|c|c|c|c|c|}
\hline \multicolumn{6}{|c|}{ Modified flamingo on the right lower limb } \\
\hline & $\begin{array}{l}\text { Statistical } \\
\text { characteristics }\end{array}$ & $\begin{array}{l}\text { Input } \\
\text { (s) }\end{array}$ & $\begin{array}{l}\text { Wilcoxon } \\
\text { test }\end{array}$ & $\begin{array}{l}\text { Output } \\
\text { (s) }\end{array}$ & $\begin{array}{l}\text { Mann W } \\
\text { U-test }\end{array}$ \\
\hline \multirow{3}{*}{$\begin{array}{l}\text { Experimental } \\
\text { group }\end{array}$} & $\mathrm{Me}$ & 31.70 & \multirow{3}{*}{$\mathrm{p} \leq 0.05$} & 39.8 & \multirow{6}{*}{$\mathrm{p} \leq 0.05$} \\
\hline & $\mathrm{X}$ & 31.74 & & 40.96 & \\
\hline & $\mathrm{Vr}$ & 37.78 & & 36.71 & \\
\hline \multirow[t]{3}{*}{ Control group } & $\mathrm{Me}$ & 31.62 & \multirow{3}{*}{$\mathrm{p} \leq 0.05$} & 32.79 & \\
\hline & $\mathrm{X}$ & 36.24 & & 38.91 & \\
\hline & $\mathrm{Vr}$ & 41.51 & & 20.14 & \\
\hline
\end{tabular}

Legend: $\mathrm{Me}$ - median, $\mathrm{X}$ - average value, $\mathrm{Vr}$ - variability range, Wilcox. Test-Wilcoxon test, Mann W. U-test - MannWitney U - test, $\mathrm{s}$ - seconds, $\mathrm{p}$-statistical significance 
As for the modified flamingo test without visual control we measured stability in the static balanced position for max. 60s. In the entry testing, the experimental group reported an average value of $31.74 \mathrm{~s}$ with the improved movement abilities after the implementation of the movement programme with the elements of basic and conditioning gymnastics and the average value of 40.96s. At the beginning of the modified flamingo test on the right lower limb, the control group reported the average value of $36.24 \mathrm{~s}$ with an increase of $2.66 \mathrm{~s}$ at the end. The results show that the probands were able to maintain the static balance for the average time of 38.91s. Based upon the statistical processing we may report significant improvement of the level of static balance abilities of the overall research group on a five-percent range. By comparing the differences, however, we may confirm a significant discrepancy for the benefit of the experimental group ( $\leq 0,05)$, which proves the effectivity of the implemented programme.

The modified flamingo testing without visual control was performed on the left lower limb. In the entry testing, we reported the average value of static balanced position of $32.51 \mathrm{~s}$ and after the experiment and implementation of the movement programme into the training practice we reported an increase by $9.48 \mathrm{~s}$ to $41.99 \mathrm{~s}$. In the entry testing, the control group reported the average value of $34.96 \mathrm{~s}$ with the exit value of $38.84 \mathrm{~s}$, which accounts for an increase of only $3.87 \mathrm{~s}$ in comparison with the experimental group. As for the Wilcoxon test, we found out that the changes to the level of static balance as diagnosed by the modified flamingo test on the left lower limb are statistically significant for the overall research group on a five-percent range of statistical significance $(\mathrm{p} \leq \mathrm{0}, 05)$. We also studied the development of the level of abilities in both the experimental and the control group after completion of the experiment. By comparing the results we found out that the level of static balance of the probands from the experimental group differs considerably or the obtained values are statistically significant $(\mathrm{p} \leq \mathrm{0}, 05)$. The above mentioned facts prove the effectivity of the implemented gymnastics movement programme for the ski jumping training practice when developing static balance abilities.

Table 4. Statistical evaluation of differences in the test of modified flamingo on the left lower limb

\begin{tabular}{|c|c|c|c|c|c|}
\hline \multicolumn{6}{|c|}{ Modified flamingo on the left lower limb } \\
\hline & $\begin{array}{l}\text { Statistical } \\
\text { features }\end{array}$ & $\begin{array}{l}\text { Entry } \\
\text { (s) }\end{array}$ & $\begin{array}{l}\text { Wilcoxon } \\
\text { test }\end{array}$ & $\begin{array}{l}\text { Exit } \\
(\mathrm{s})\end{array}$ & $\begin{array}{l}\text { Mann W } \\
\text { U-test }\end{array}$ \\
\hline \multirow{3}{*}{$\begin{array}{l}\text { Experimental } \\
\text { group }\end{array}$} & $\mathrm{Me}$ & 32.80 & \multirow{3}{*}{$\mathrm{p} \leq 0.05$} & 40.35 & \multirow{6}{*}{$\mathrm{p} \leq 0.05$} \\
\hline & $\mathrm{X}$ & 32.51 & & 41.98 & \\
\hline & $\mathrm{Vr}$ & 33.89 & & 32 & \\
\hline \multirow{3}{*}{$\begin{array}{l}\text { Control } \\
\text { group }\end{array}$} & $\mathrm{Me}$ & 30.45 & \multirow{3}{*}{$\mathrm{p} \leq 0.05$} & 33.01 & \\
\hline & $\mathrm{X}$ & 34.96 & & 38.84 & \\
\hline & $\mathrm{Vr}$ & 43.58 & & 37.81 & \\
\hline
\end{tabular}

Key: $\mathrm{Me}$ - median, $\mathrm{X}$ - average value, $\mathrm{Vr}$ - variability range, Wilcox. Test-Wilcoxon test, Mann W. U-test - MannWitney U - test, s - seconds, $\mathrm{p}$-statistical significance

\section{Conclusion}

In the present paper we conducted the study focusing on the development of balance abilities in course of a twelve-week long preparatory period. Even though the literature says that sensitive periods for development of balance abilities start at the age of 9, we could have presumed that through right direction and under the properly implemented gymnastics practice, such abilities may be influenced at much younger age. The main aim of our paper was to prove effectivity of the implemented gymnastics programme for balance abilities of ski jumpers at younger school age. After evaluation and comparison of the results of the research we may draw the conclusion that the probands having been under the influence of the experimental agent had reported considerable positive changes. We may assume that the proper application of the training programme consisting of conditioning and basic gymnastics may have a positive impact on balance abilities of sportsmen. The arithmetic index (x) was used for comparing the improvements and drawing unambiguous conclusions from our research. The so-called flamingo tests were applied to determine the changes to static balance. The test on the right lower limb in the probands under the influence of the experimental agent reported the average difference of 6.56s between the entry and exit tests with 
the statistical significance of $\mathrm{p} \leq \mathrm{0,05}$. The flamingo test on the left lower limb reported the average increase of 2.01s, which also confirms the five-percent statistical significance. The modified flamingo test on the right lower limb reported significant improvement by $9.22 \mathrm{~s}$ and that on the left lower limb by $9.48 \mathrm{~s}$. In both cases the progress within statistical significance ranged around $\mathrm{p} \leq \mathrm{0,05}$. The given results demonstrate that our presumption about the increase in the level of balance abilities under the influence of the experimental agent has been confirmed. Consequently our movement programme including the elements of basic and conditioning gymnastics could be certainly implemented into our training practice.

\section{References}

Belej, Junger, 2006 - Belej, M., Junger, J. a kol. (2006). Motorické testy koordinačných schopností. Prešov: PU FŠ.

Böhmerová, 2006 - Böhmerová, L. (2006). Gymnastická príprava ako rozvoj rovnováhových schopností v školskej telesnej výchove. Ako využívat' gymnastiku, aerobik, tance, fitnes a úpoly na zdokonal'ovanie človeka: Zborník z workshopu poriadaného Katedrou gymnastiky dňa 23. 02. 2006. Bratislava: Univerzita Komenského, Fakulta telesnej výchovy a športu, pp. 60-64.

Bohmerová, 2007 - Bohmerová, L'. (2007). Rovnováhové schopnosti športových gymnastiek rôzneho veku a výkonnosti. Bratislava. Dizertačná práca. Univerzita Komenského v Bratislave, Fakulta telesnej výchovy a športu, Katedra športovej kinantropológie.

Havel, Hnízdil, 2010 - Havel, Z., Hnízdil, J. (2010). Rozvoj a diagnostika koordinačních a pohyblivostních schopností. Banská Bystrica: PF UMB, 176 p.

Kasa, 2002 - Kasa J. (2002). Športová antropomotorika. Bratislava : FTVŠ UK, 87 p.

Liberum Montessori Akademia, 2017 - Liberum Montessori Akademia (2017, Ocak 8). Proprioseptif (Derin Duyu). Mayls 26, 2018 tarihinde. [Electronic resource]. URL: http://www.montessoriakademia.com/2017/ 01/o8/proprioseptif-derin-duyu/adresinden alındı.

Laczo, 2013 - Laczo, E. a kol. (2013). Rozvoj a diagnostika pohybových schopností detí a mládeže. Bratislava: Národné športové centrum, 154 p.

Lednický, Doležajová, 2002 - Lednický, A., Doležajová L. (2002). Rozvoj koordinačných schopností. Bratislava: ICM Agency.

Mandzák, Mandzáková, 2002 - Mandzák, P., Mandzáková, M. (2002). Vplyv plávania na rozvoj vytrvalostných schopností žiaka mladšieho školského veku. Acta Universitatis Matthiae Belii: telesná výchova a šport. Vol. 4, no. 4. Banská Bystrica: Pedagogická fakulta UMB, pp. 45-49.

Mandzák et al., 2018 - Mandzák, P., Slováková, M., Krull, J. (2018). Longitudiálne zmeny pohybových schopností vplyvom intervenčného pohybového programu. In: Aktuálne problémy telesnej výchovy a športu VII. Zborník vedeckých prác. Ružomberok : Katolícka univerzita, pp. 14-22.

Měkota, Novosad, 2005 - Měkota, K., Novosad, J. (2005). Motorické schopnosti. Olomouc: Univerzita Palackého v Olomouci, 175 p.

Měkota, Novosad, 2005 - Měkota, K., Novosad, J. (2005). Motorické schopnosti. 1. vyd. Olomouc: Univerzita Palackého v Olomouci, 175 p.

Moravec et al., 2002 - Moravec, R., Kampmiller, T., Sedláček, J. a kol. (2002). Eurofit Telesný rozvoj a pohybová výkonnost’ školskej populácie na Slovensku.2. Vyd. Bratislava: SVSTVS, $80 \mathrm{p}$.

Neuman, 2003 - Neuman, J. (2003). Cvičení a testy obratnosti vytrvalosti a sily. Praha: Portál s.r.o., $160 \mathrm{p}$.

Paugschová et al., 2010 - Paugschová, B., Daubnerová, J., Ondráček, J. (2010). Biorythmic changes in the development of velocity and power abilities in biathlon = Biorytmické zmeny $\mathrm{v}$ rozvoji pohybových schopností a streleckých zručností v biatlone. In Studia Sportiva. Brno: Masarykova univerzita, Fakulta sportovních studií, roč. 4, č. 1. pp. 25-34.

Perečinská, 2006 - Perečinská, K. (2006). Rovnováhové schopnosti. In: Belej M., Junger, J. a kol.: Motorické testy koordinačných schopností. FŠ PU v Prešove.

Plešivčáková, 2013 - Plešivčáková, B. (2013). Prípravné cvičenia športovej gymnastiky na hodinách telesnej a športovej výchovy. Banská Bystrica: Metodicko-pedagogické centrum [online].[cit. 1. júna 2016].

Perič, 2004 - Perič, T. (2004). Sportovní př́íprava dětí. Praha: Grada. 
Strešková, 2005 - Strešková, E. (2005). Stratégia rozvoja koordinačných schopností u mládeže. Rozvoj koordinačných schopností v športovej príprave. Bratislava: Telovýchovná škola SZTK, pp. 7-24.

Strešková, 2010 - Strešková, E. (2010). Zmeny rovnováhovej schopnosti a vestibulárneho analyzátora u detí predškolského a mladšieho školského veku. In: E. Strešková a kol. Úroveň rovnováhových schopností a vestibulárneho analyzátora $v$ gymnastických, tanečných a úpolových športoch: Zborník prác z výsledkov grantovej úlohy VEGA. 1. vyd. Bratislava: ICM Agency, pp. 72-88.

Šimonek, 2012 - Šimonek, J. (2012). Testy pohybových schopností. Nitra: Dominant Nitra, $194 \mathrm{p}$.

Zemková, 2008 - Zemková, E. (2008). Diagnostika koordinačných schopností. Bratislava: Univerzita Komenského, 116 p. 